\title{
Evaluation of Porridge Made from Composite Flour of Orange-Fleshed Sweet Potato and Enset (Bulla) Flours
}

\author{
Abebe Haile ${ }^{1}$ \\ Martha Geribo 2 \\ Esayas $\mathrm{Kinfe}^{3}$ \\ 1,2,3 Hawassa University, Awassa College of Agriculture, \\ School of Nutrition, Food Science and Technology, \\ Awassa, Ethiopia \\ ( Corresponding Author)
}

\begin{abstract}
Bulla is the water insoluble starchy product which is separated from Kocho during the decortications process of Enset. However, this extract lacks pro-vitamin A. This study enriched the Bulla with Orangefleshed Sweet Potato (OFSP) a plant with high levels of $\beta$-carotene that can be useful for combating vitamin A deficiency. The porridge was made of composite flours of bulla blended with 30, 35, 40 and $45 \%$ OFSP flours were investigated for proximate composition, $\beta$-carotene, functional property and sensory acceptability of products using standard methods. The data were analyzed using SAS 1.9 Software. The composite flours percentage moisture, crude (fiber, protein, fat), ash, carbohydrate, gross energy, $\beta$-carotene, $\mathrm{pH}$, bulk density and water absorption capacity were found to be in the range of 29.54 to 40.25 , (1.66 to $2.05,2.11$ to $2.55,0.55$ to 0.71$), 1.76$ to $2.11,53.86$ to $63.31,227.49$ to 268.11 $\mathrm{Kcal} / 100 \mathrm{~g}, 386.68$ to $558.05 \mu \mathrm{g} / 100 \mathrm{~g}, 4.46$ to $5.71,0.58$ to 0.80 and 1.70 to $4.87 \mathrm{ml} / \mathrm{g}$, respectively. While, the composite flours porridge percentage moisture, crude fiber, ash, crude protein, crude fat, carbohydrate, gross energy, $\beta$-carotene, $\mathrm{pH}$ and viscosity content found to be in the range from 43.42 to $58.03,1.32$ to $1.79,2.39$ to $2.78,2.01$ to $2.31,0.71$ to $0.82,35.21$ to $48.63,155$ to $211.11 \mathrm{Kcal} / 100 \mathrm{~g}$, 201.46 to $301.50 \mu \mathrm{g} / 100 \mathrm{~g}, 5.71$ to 5.82 and 515 to $728 \mathrm{cps}$, respectively. The porridge $\mathrm{OB}_{4} \mathrm{PM}_{2}(45 \%$ OFSP and 55\% Bulla) was most preferred due to its color, odor, flavor and overall acceptability with panelist scored value of 4.28, 4.33, 4.39 and 4.45, respectively. Moreover, $\mathrm{OB}_{4} \mathrm{PM}_{2}$ porridge was found to be good source of ash, energy and $\beta$-carotene content.
\end{abstract}

Keywords: Bulla, Composite flour, Orange-fleshed sweet potato, Porridge, $\beta$-carotene, Viscosity.

\section{Contents}

1. Introduction.

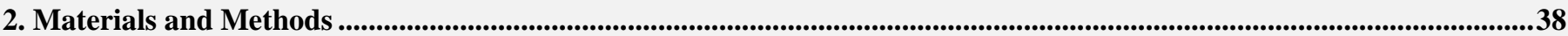

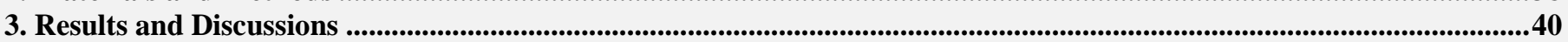

4. Conclusion 43

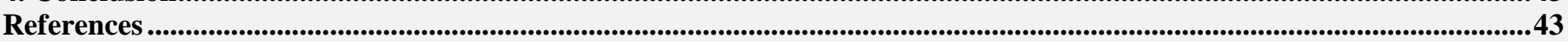

Citation | Abebe Haile; Martha Geribo; Esayas Kinfe (2016). Evaluation of Porridge Made from Composite Flour of Orange-fleshed Sweet Potato and Enset (Bulla) Flours. Agriculture and Food Sciences Research, 3(1): 37-44.

DOI: $10.20448 /$ journal.512/2016.3.1/512.1.37.44 crossref

ISSN(E) : $\quad 2411-6653$

ISSN(P) : $\quad 2411-6653$

Licensed: $\quad$ This work is licensed under a Creative Commons Attribution 3.0 License $\left({ }^{(c)}\right) \mathbf{E}$

Contribution/Acknowledgement: All authors contributed to the conception and design of the study.

Funding: $\quad$ This study received no specific financial support.

Competing Interests: The authors declare that they have no conflict of interests.

Transparency: $\quad$ The authors confirm that the manuscript is an honest, accurate, and transparent account of the study was reported; that no vital features of the study have been omitted; and that any discrepancies from the study as planned have been explained.

History:

Ethical:

Publisher:

Received: 14 April 2016/ Revised: 6 May 2016/ Accepted: 18 May 2016/ Published: 13 June 2016

This study follows all ethical practices during writing.

Asian Online Journal Publishing Group 


\section{Introduction}

Bulla is a processed starch made from Enset (Enset ventricosum). It is obtained when the scrapings and pulps were squeezed, separating of the liquid. Collecting the pulpy white juice and left for one or two days to settle the resultant starch to concentrate into white flour. The starch that separates out from the liquid concentrates into a white powder. This product can be either fermented in pit or directly cooked without fermentation [1,2]. Bulla is a good source of calories. It can be prepared as pancake, porridge and made into soup. Bulla fulfills both the nutritional requirement and income of the family there by providing household financial security that is by frequent sale of some amounts of fermented Bulla from the storage pit. The price of bulla is higher than Kocho even at local market [1]. Bulla can be stored for a long period of time without spoiling. The shelf life of Bulla depends on the age of the harvested Enset plant and the way of packing system. Proper packaging is needed to protect the spoilage. If there are pockets of air, or exposed to air, molds and other spoilage organisms can grow and soften the product. Due to its moisture content there will be taste and color change happen to the product [3].

Bulla was considered the best quality Enset food. However, it is low in protein, fat content and has no adequate pro-vitamin A for the daily requirement of a normal person. According to the study of Minaleshewa [2] and Tilahun, et al. [4] protein and fat content of Bulla were renged from 0.4-0.8 and 0.2-0.4g, respectively. The Vitamin " $A$ " content of Enset products record was $0-0.2 \%$ [4]. As a result, it is a problem for those people who use Enset product (Bulla) as staple or co-staple food have a chance of being affected by vitamin A deficiency.

Orange-fleshed Sweet Potato (Ipomoea batatas) is an important tuber crop grown in the tropics, sub-tropics and warm temperate regions of the world for its edible roots crop. The roots contain significant amount of carbohydrate constitute mainly in the forms of starch, sugar and dietary fibers, which play an important role of providing low-cost energy in the diet of consumers. Beside carbohydrate, it contains high levels of $\beta$-carotene and appreciable amount of minerals. Orange-fleshed Sweet Potato (OFSP) varieties are being promoted as food based intervention to combat vitamin A malnutrition [5]. The flesh color of the root varies from various shades of white, cream, yellow to darkorange depending upon the carotenoids content [6]. Carotenoids have been linked with the enhancement of immune system and decreased risk of degenerative diseases such as cardiovascular problems. Dietary fiber has the potential to reduce the incidence of a variety of diseases in man including colon cancer, diabetes, heart diseases and digestive disturbances [7]. The primary role of enriching the Enset product (Bulla) with Orange-fleshed Sweet Potato was to upgrade the Vitamin A content of the products. It is the intervention falls in the latter category of food based approaches which is particularly suited for rural areas where the Enset products used as a staple food. A food based strategy has the advantage of bringing more nutrients, vitamin "A" and more sustainable approach. Enriching the indigenous root crop Enset product (Bulla) by mixing with orange-fleshed sweet potato can be a good solution to improve the nutritional quality of household diets.

Vitamin A is a fat-soluble vitamin that was needed in small quantities for several metabolic activities in the body. When vitamin A intake is below required levels, a number of manifestations collectively known as vitamin A deficiency (VAD) disorders occur. This vitamin deficiency has manifested as blindness, increased susceptibility to infection and closely associated with increased mortality and morbidity [8]. The causes of VAD occurs when vitamin A intake or liver stores fail to meet daily metabolic requirements and the most common cause is a persistently low intake of vitamin A-rich foods. Therefore, the objective of this study is enriching of Enset product (Bulla) flour with Orange-fleshed Sweet Potato to prepare porridge of having high vitamin A content from the blended flours. Moreover, to determine the physicochemical, $\beta$-carotene content and sensory acceptability of the products.

\section{Materials and Methods}

\subsection{Sample Collection}

Raw Bulla sample was purchased from Hawassa local market. Raw Orange-fleshed Sweet Potato of Tulla variety (CIP-420027) was collected from Southern Agricultural Research Center of Primary Quality Sweet Potato Vine Multiplication Center (Wondo Genet Farm). All the samples were properly packed and transported to the laboratory of Food Science and Technology, Hawassa University. The OFSP was stored at $-18{ }^{\circ} \mathrm{C}$ (Haier chest freezer Model HCF 588) to protect spoilage. While Bulla was stored at dry and ambient temperature until further processing.

\subsection{Bulla Flour Preparation}

Bulla sample was prepared according to procedure outlined by Minaleshewa [2]. The semi dried bulk Bulla sample was spreaded on clean dry wood board and the long fibers were removed manually. The sample was then sieved through 500 $\mu$ m sieve (FRITSCH, test sieve, Made in German) to remove the hard particles and made it uniform size and the contents were mixed. Bulla flour was packed by polyethylene bag and stored at room temperature.

\subsection{Orange-fleshed Sweet Potato Flour Preparation}

Orange-fleshed sweet potato flour was prepared according to the procedure outlined by Owori, et al. [9]. The OFSP was taken out from deep freezer and kept on the laboratory table for four hours until its temperature was raised to room temperature. The OFSP was washed with potable water to remove any foreign bodies and then the outer skin was peeled by peeling machine (Robot coupé H. Biaugeaup Model CL 30). The remaining unnecessary parts were removed manually and rinsed by clean potable water. The OFSP was chopped to minimize the size for the slicer machine. The chopped sweet potato was then sliced to a uniform size of $3 \mathrm{~mm}$ by the slicer machine (H. Biaugeaup Model W1 9901). The slices were soaked in $1 \% \mathrm{w} / \mathrm{v}$ sodium chloride solution for 30 minutes. The function of salt is to inhibit the growth of microorganisms on the slices while drying. The slices were dried on the flat racks of solar dryer. The dried sample was milled by electronic grinder and sieved by $500 \mu \mathrm{m}$ sieve (FRITSCH, test sieve, Made in German). The flour obtained was double packed by dark polyethylene bags stored in dry and dark place to protect oxidation of $\beta$ - carotene. 


\subsection{Preparation of OFSP Added Bulla Composite Flour}

The formulation of OFSP with Bulla for porridge making were done based on the recommended dietary intake (RDI) of adult person to maintain a healthy life. It also allows creating unique and delicious recipes based on the acceptability of the users, see Table 1 below.

Table-1. Proportion of OFSP powder used to formulate the composite flour

\begin{tabular}{l|l|l|l|l|l}
\hline \multicolumn{6}{l}{ Bulla composition /Kg } \\
\hline & $\mathbf{O B}_{\mathbf{4}} \mathbf{P M} \mathbf{M}_{\mathbf{1}}$ & $\mathbf{O B}_{\mathbf{3}} \mathbf{P M}_{\mathbf{1}}$ & $\mathbf{O B}_{\mathbf{2}} \mathbf{P M}_{\mathbf{1}}$ & $\mathbf{O B}_{\mathbf{1}} \mathbf{P M}_{\mathbf{1}}$ & $\mathbf{B}_{\mathbf{1}} \mathbf{P M}_{\mathbf{1}}$ \\
\hline OFSP & $45 \%$ & $40 \%$ & $35 \%$ & $30 \%$ & - \\
\hline Bulla & $55 \%$ & $60 \%$ & $65 \%$ & $70 \%$ & $100 \%$ \\
\hline Total & $1 \mathrm{Kg}$ & $1 \mathrm{Kg}$ & \multicolumn{1}{l}{$1 \mathrm{Kg}$} & $\mathrm{Kg}$ \\
\hline Note: $* \mathrm{PM}_{1} \rightarrow$ is the code of treatments before cooking
\end{tabular}

Table-2. Proportion of ingredients used to prepare porridge

\begin{tabular}{|c|c|c|c|c|c|}
\hline \multicolumn{6}{|c|}{ Bulla composite flour porridge /kg } \\
\hline & OB4PM2 & OB3PM2 & OB2PM2 & OB1PM2 & B1PM2 \\
\hline OFSP & $45 \%$ & $40 \%$ & $35 \%$ & $30 \%$ & - \\
\hline Bulla & $55 \%$ & $60 \%$ & $65 \%$ & 70 & $100 \%$ \\
\hline Water $(\mathrm{mL} / \mathrm{kg})$ & 1500 & 1500 & 1500 & 1500 & 1500 \\
\hline Oil (mL/kg) & 20 & 20 & 20 & 20 & 20 \\
\hline
\end{tabular}

$\mathrm{B}_{1} \mathrm{PM}_{1}=100 \%$ of Bulla flour, $\mathrm{OB}_{1} \mathrm{PM}_{1}=30 \%$ OFSP $+70 \%$ of Bulla, $\mathrm{OB}_{2} \mathrm{PM}_{1}=35 \%$ OFSP $+65 \%$ of Bulla, $\mathrm{OB}_{3} \mathrm{PM}_{1}=40 \%$ OFSP $+60 \%$ of Bulla and $\mathrm{OB}_{4} \mathrm{PM}_{1}=45 \%$ OFSP $+55 \%$ of Bulla composite flour; $\mathrm{B}_{1} \mathrm{PM}_{2}=100 \%$ Bulla porridge, $\mathrm{OB}_{1} \mathrm{PM}_{2}=30 \%$ OFSP $+70 \%$ Bulla, $\mathrm{OB}_{2} \mathrm{PM}_{2}=35 \%$ OFSP $+65 \%$ of Bulla, $\mathrm{OB}_{3} \mathrm{PM}_{2}=40 \%$ OFSP $+60 \%$ Bulla and $\mathrm{OB}_{4} \mathrm{PM}_{2}=45 \%$ OFSP $+55 \%$ Bulla composite flour porridge.

\subsection{Porridge Preparation}

Bulla based porridge was prepared using the methods outlined by Yewelsew, et al. [10]. One kilogram of composite flours was mixed with $1500 \mathrm{~mL} / \mathrm{kg}$ of water, kneaded well in the pot, and boiled until all particles became soluble while boiling $20 \mathrm{~mL}$ oil was added. Then the composite flour porridge was cooked at the temperature of 100 ${ }^{0} \mathrm{C}$ for 10 minutes.

\subsection{Chemical Analysis}

\subsubsection{Determination of $\beta$-carotene Contents}

B-carotene content in the food was determined as the procedure outlined by Rodriguez, et al. [11] based on Spectro-photometric test.

\subsubsection{Determination of Proximate Composition}

The Proximate composition of flour and composite flour porridge were determined by using the standard method of Association of Official Analytical Chemists (AOAC) [12]. The total carbohydrate amount in the sample was determined by difference:

Total carbohydrate $\%=\mathbf{1 0 0}-(\mathbf{P}+\mathbf{F}+\mathbf{A}+\mathbf{M})$

Whereas: $\mathrm{P}=$ the mass percentage of crude protein,

$\mathrm{F}=$ the mass percentage of crude fat

$\mathrm{A}=$ the mass percentage of ash,

$\mathrm{M}=$ the mass percentage of moisture

\subsubsection{Determination of Gross Energy}

The energy value was determined by calculation using the relationship from fat, carbohydrate and protein contents of the Atwater's Conversion Factors; (4kcal/g) for protein, $(9 \mathrm{kcal} / \mathrm{g})$ for fat and $(4 \mathrm{kcal} / \mathrm{g})$ for carbohydrates and expressed in calories.

$$
\text { Gross energy }(\mathrm{kcal} / \mathrm{g})=(4 \times \text { protein })+(4 \times \text { carbohydrate })+(9 \times \text { fat })
$$

\subsection{Determination of Physical and Functional Properties}

\subsection{1. pH Value}

The $\mathrm{pH}$ of the samples was determined from 1/10 dilution of sample by glass electrode attached to digital $\mathrm{pH}$ meter as their combination ratio before cooking and after cooking of each composite flours samples were done according to the method described by Yirmaga [13]. The pH meter (MP 511 Lab. pH meter, China) was calibrated using $\mathrm{pH} 4.0$ and 7.0 buffers prior to determination of the $\mathrm{pH}$ of the samples.

\subsubsection{Bulk Density}

The bulk density of OFSP added Bulla composite flours were determined by using method [14]. 


\subsubsection{Water Absorption Capacity}

Water absorption capacity OFSP added Bulla composite flours were determined using the method [15].

\subsection{Viscosity}

The viscosities of the composite flours porridge were measured using the method of [16].

\subsection{Sensory Evaluation}

Sixty-two panelists who were the students of the School of Nutrition, Food Science and Technology, Hawassa University did the consumer acceptability of composite flour porridge. The panelists ranked the color, odor, flavor, and overall acceptability of composite flours porridge using a five point hedonic scale (5 Extreme like, 4 Like very much, 3 Like, 2 Dislike and 1 Dislike very much). The composite flours porridge samples were presented in triplicate. Samples were being ordered on the table without providing any information to the panelists. A bottle of tape water with white plastic cups was given to rinse their mouth after each test. They use their observation and sense organ on making decisions, and they interpret the nature of a sample. The results were recorded and analyzed to determine the significance of variations of sensory attributes of the products average scores.

\subsection{Ethical Approval}

The study protocol was approved by the ethical committee of Hawassa University College of Medicine and Health Science for sensory evaluations.

\subsection{Statistical Analysis}

The data were analyzing using the SAS 9.1 Software. Analysis of variance (ANOVA) was used for the analysis. Fisher`s Least Significance Difference (LSD) test was used to determine the significance of mean differences of the results. The level of statistical significance was set at $(\mathrm{p}<0.05)$.

\section{Results and Discussions}

\subsection{Proximate Composition, Physicochemical and Functional Properties}

Table-3. Proximate composition (\%) of OFSP added Bulla composite flours and porridge.

\begin{tabular}{|c|c|c|c|c|}
\hline Treatment & Moisture content & Crud fiber & Ash & Crude protein \\
\hline \multicolumn{5}{|c|}{ Composite flours } \\
\hline $\mathrm{B}_{1} \mathrm{PM}_{1}$ & $48.25 \pm 0.01 \mathrm{~d}$ & $0.39 \pm 0.01 \mathrm{i}$ & $1.26 \pm 0.01 \mathrm{i}$ & $1.06 \pm 0.01 \mathrm{~h}$ \\
\hline $\mathrm{OB}_{1} \mathrm{PM}_{1}$ & $40.38 \pm 0.00 \mathrm{~g}$ & $1.66 \pm 0.01 \mathrm{e}$ & $2.11 \pm 0.01 \mathrm{~g}$ & $1.76 \pm 0.01 \mathrm{~g}$ \\
\hline $\mathrm{OB}_{2} \mathrm{PM}_{1}$ & $33.72 \pm 0.01 \mathrm{~h}$ & $1.81 \pm 0.00 \mathrm{c}$ & $2.24 \pm 0.01 \mathrm{f}$ & $1.88 \pm 0.01 \mathrm{e}$ \\
\hline $\mathrm{OB}_{3} \mathrm{PM}_{1}$ & $31.62 \pm 0.01 \mathrm{i}$ & $1.92 \pm 0.01 \mathrm{~b}$ & $2.38 \pm 0.01 \mathrm{e}$ & $2.01 \pm 0.01 \mathrm{~d}$ \\
\hline $\mathrm{OB}_{4} \mathrm{PM}_{1}$ & $29.54 \pm 0.01 \mathrm{j}$ & $2.05 \pm 0.01 \mathrm{a}$ & $2.55 \pm 0.00 \mathrm{c}$ & $2.11 \pm 0.01 \mathrm{c}$ \\
\hline \multicolumn{5}{|l|}{ Porridge } \\
\hline $\mathrm{B}_{1} \mathrm{PM}_{2}$ & $60.30 \pm 0.01 \mathrm{a}$ & $0.12 \pm 0.01 \mathrm{j}$ & $2.00 \pm 0.01 \mathrm{~h}$ & $1.90 \pm 0.00 \mathrm{f}$ \\
\hline $\mathrm{OB}_{1} \mathrm{PM}_{2}$ & $58.03 \pm 0.01 b$ & $1.32 \pm 0.01 \mathrm{~h}$ & $2.39 \pm 0.01 \mathrm{e}$ & $2.01 \pm 0.00 \mathrm{~d}$ \\
\hline $\mathrm{OB}_{2} \mathrm{PM}_{2}$ & $50.11 \pm 0.01 \mathrm{c}$ & $1.49 \pm 0.01 \mathrm{~g}$ & $2.51 \pm 0.01 \mathrm{~d}$ & $2.12 \pm 0.01 \mathrm{c}$ \\
\hline $\mathrm{OB}_{3} \mathrm{PM}_{2}$ & $46.75 \pm 0.01 \mathrm{e}$ & $1.62 \pm 0.01 \mathrm{f}$ & $2.62 \pm 0.01 \mathrm{~b}$ & $2.21 \pm 0.01 \mathrm{~b}$ \\
\hline $\mathrm{OB}_{4} \mathrm{PM}_{2}$ & $43.42 \pm 0.00 \mathrm{f}$ & $1.79 \pm 0.01 \mathrm{~d}$ & $2.78 \pm 0.01 \mathrm{a}$ & $2.31 \pm 0.01 \mathrm{a}$ \\
\hline
\end{tabular}

$\mathrm{B}_{1} \mathrm{PM}_{1}=100 \%$ of Bulla flour, $\mathrm{OB}_{1} \mathrm{PM}_{1}=30 \%$ OFSP $+70 \%$ of Bulla, $\mathrm{OB}_{2} \mathrm{PM}_{1}=35 \%$ OFSP $+65 \%$ of Bulla, $\mathrm{OB}_{3} \mathrm{PM}_{1}=40 \%$ OFSP $+60 \%$ of Bulla and $\mathrm{OB}_{4} \mathrm{PM}_{1}=45 \%$ OFSP $+55 \%$ of Bulla composite flour; $\mathrm{B}_{1} \mathrm{PM}_{2}=100 \%$ Bulla porridge, $\mathrm{OB}_{1} \mathrm{PM}_{2}=30 \% \mathrm{OFSP}+70 \%$ Bulla, $\mathrm{OB}_{2} \mathrm{PM}_{2}=35 \%$ OFSP $+65 \%$ of Bulla, OB $\mathrm{PM}_{2}=40 \%$ OFSP + $60 \%$ Bulla and $\mathrm{OB}_{4} \mathrm{PM}_{2}=45 \%$ OFSP $+55 \%$ Bulla composite flour porridge. Means \pm SD, values within the same column with different superscript letters are significantly different from each other $(\mathrm{p}<0.05)$.

Table 3 shows that the moisture content of OFSP and Bulla composite flours and porridges were ranged from $31.62-48.25 \%$ and 43.42-60.30\%, respectively. The highest moisture content observed in $\mathrm{B}_{1} \mathrm{PM}_{2}(60.30 \%)$ followed by $\mathrm{OB}_{1} \mathrm{PM}_{2}(58.03 \%)$ and the least was for the $\mathrm{OB}_{4} \mathrm{PM}_{1}(29.54 \%)$. Moisture content of OFSP and Bulla composite flour and porridge were significantly different $(\mathrm{p}<0.05)$ to each other. According to Kalekristos [3] the moisture content of Bulla bought from Addis Ababa supper market was found in the range of 44 to $57 \%$, that was contain more moisture than the present study. There were significant differences in moisture content between the treatments, before and after cooking of the porridge. The highest moisture content of composite flours and porridges scores were $\left(\mathrm{OB}_{1} \mathrm{PM}_{1}\right) 40.38 \%$ and $\mathrm{OB}_{1} \mathrm{PM}_{2}(58.03 \%)$, respectively. The difference might be due to addition of more water while cooking the porridge. As the amount of OFSP flour increases in the composite flours, the moisture content of flour and porridge were decreased gradually.

Crud fiber contents of Bulla 0.39\%, OFSP added Bulla composite flour ranged from 1.66 to $2.05 \%$, while Bulla porridge ranged from 0.12 to $1.79 \%$. There were significant difference $(\mathrm{p}<0.05)$ among the treatments. Higher crude fiber $(2.05 \%)$ content was obtained in Bulla based composite flour $\mathrm{OB}_{4} \mathrm{PM}_{1}$, while the lowest $(0.12 \%)$ was obtained for porridge $\mathrm{B}_{1} \mathrm{PM}_{2}$. According to the previous reported literature, Bulla was the decanted fluid of the decortications processing of Enset plant and it is very poor in fiber content of recorded values were in the range from 0.6 to $0.8 \%$ [3]. As the amount of OFSP flour increases in the composite flours, the fiber content increased gradually. This might be due to the crude fiber content of OFSP more than Bulla flour. However, the fiber content of OFSP added Bulla composite flours were not fulfilling the RDA of fiber for healthy adult. According to FAO Food Standards Program 
[17] of the RDA of fiber for healthy person set at 25 to $38 \mathrm{~g} /$ day which was significantly different from the present study. Hence, Bulla composite flours porridge needs additional fiber source of food.

Ash actually a much more general term that can refer to a number of substances in the food. The ash is residue that remains after heating and removing water or it refers to any inorganic material present in food [18]. The ash content of OFSP added Bulla composite flour and porridge were ranged from 1.26-2.55\% and 2.39 - 2.78\%, respectively. According to Minaleshewa [2] and Yirmaga [13] the ash content of Bulla was found 0.2 and $2.39 \%$, respectively. The highest ash content was observed for $\mathrm{OB}_{4} \mathrm{PM}_{2}(2.78 \%)$ whereas the least for $\mathrm{B}_{1} \mathrm{PM}_{1}(1.26 \%)$. The ash content of composite flours and porridges were significantly different $(\mathrm{p}<0.05)$ to each other. It might be due to the leaching of some minerals from cooking utensils. As the amount of OFSP flour increased in the composite flours, the crude ash content increased. The increment of ash content show that the increasing the density of inorganic material such as minerals present in food.

The protein value for different Bulla based composite flour and porridge were presented in Table 3 shows that the highest protein record was for $\mathrm{OB}_{4} \mathrm{PM}_{2}(2.31 \%)$ and the least was observed for $\mathrm{B}_{1} \mathrm{PM}_{1}(1.06 \%)$. There were significant different $(\mathrm{p}<0.05)$ observed among protein content except for $\mathrm{OB}_{4} \mathrm{PM}_{1}$ and $\mathrm{OB}_{3} \mathrm{PM}_{1}$. The crude protein content of Bulla was recorded 1.6g/100 g while the protein content of OFSP added Bulla composite flour was in the range of 1.76 to $2.11 \%$. These, value were greater than the crude protein content of Bulla reported values of 0.6 and 0.4-0.8 g/100g by Tilahun, et al. [4] and Minaleshewa [2] respectively. The highest protein content of Bulla composite porridge score was $(2.31 \%)$ observed in $\mathrm{OB}_{4} \mathrm{PM}_{2}$. When the percentage of OFSP increases, the protein content of composite flour increased gradually. This might be due to relatively higher protein content of OFSP compared to Bulla. However, protein contents of the composite flours were not enough for daily requirement of healthy person which was in the range of 0.80 to $1.52 \mathrm{~g} / \mathrm{kg} / \mathrm{d}[17,18]$.

Table-4. Proximate composition (\%) of crude fat, carbohydrate, energy and $\beta$-carotene of composite flours and porridges

\begin{tabular}{l|l|l|l|l}
\hline Treatment & Crude fat & Total carbohydrate & Gross energy, Kcal/100gm & $\boldsymbol{\beta}$-carotene, $\boldsymbol{\mu g} / \mathbf{1 0 0 g m}$ \\
\hline Composite flours & & & & \\
\hline $\mathrm{B}_{1} \mathrm{PM}_{1}$ & $0.26 \pm 0.00 \mathrm{~h}$ & $48.78 \pm 0.02 \mathrm{e}$ & $201.07 \pm 0.00 \mathrm{f}$ & $\mathrm{Nil}$ \\
\hline $\mathrm{OB}_{1} \mathrm{PM}_{1}$ & $0.55 \pm 0.01 \mathrm{~g}$ & $53.86 \pm 0.01 \mathrm{~d}$ & $227.49 \pm 0.07 \mathrm{~d}$ & $386.68 \pm 0.04 \mathrm{~d}$ \\
\hline $\mathrm{OB}_{2} \mathrm{PM}_{1}$ & $0.59 \pm 0.01 \mathrm{f}$ & $60.09 \pm 0.01 \mathrm{c}$ & $253.19 \pm 0.04 \mathrm{c}$ & $451.13 \pm 0.02 \mathrm{c}$ \\
\hline $\mathrm{OB}_{3} \mathrm{PM}_{1}$ & $0.64 \pm 0.00 \mathrm{e}$ & $61.73 \pm 0.02 \mathrm{~b}$ & $260.33 \pm 0.61 \mathrm{~b}$ & $515.58 \pm 0.03 \mathrm{~b}$ \\
\hline $\mathrm{OB}_{4} \mathrm{PM}_{1}$ & $0.71 \pm 0.01 \mathrm{~d}$ & $63.31 \pm 0.00 \mathrm{a}$ & $268.11 \pm 0.05 \mathrm{a}$ & $558.05 \pm 0.00 \mathrm{a}$ \\
\hline Porridges & & & & \\
\hline $\mathrm{B}_{1} \mathrm{PM}_{2}$ & $0.22 \pm 0.01 \mathrm{i}$ & $35.00 \pm 0.00 \mathrm{~h}$ & $149.58 \pm 0.05 \mathrm{j}$ & $\mathrm{Nil}$ \\
\hline $\mathrm{OB}_{1} \mathrm{PM}_{2}$ & $0.71 \pm 0.01 \mathrm{~d}$ & $35.21 \pm 0.00 \mathrm{~h}$ & $155.27 \pm 0.00 \mathrm{i}$ & $201.46 \pm 0.34 \mathrm{~h}$ \\
\hline $\mathrm{OB}_{2} \mathrm{PM}_{2}$ & $0.74 \pm 0.01 \mathrm{c}$ & $42.71 \pm 0.02 \mathrm{~g}$ & $185.98 \pm 0.05 \mathrm{~h}$ & $231.54 \pm 0.03 \mathrm{~g}$ \\
\hline $\mathrm{OB}_{3} \mathrm{PM}_{2}$ & $0.78 \pm 0.00 \mathrm{~b}$ & $45.71 \pm 0.02 \mathrm{f}$ & $198.72 \pm 0.06 \mathrm{~g}$ & $265.71 \pm 0.01 \mathrm{f}$ \\
\hline $\mathrm{OB}_{4} \mathrm{PM}_{2}$ & $0.82 \pm 0.01 \mathrm{a}$ & $48.63 \pm 0.01 \mathrm{e}$ & $211.11 \pm 0.07 \mathrm{e}$ & $301.50 \pm 0.02 \mathrm{e}$ \\
\hline
\end{tabular}

Note: $* \mathrm{PM}_{1} \rightarrow$ treatments before cooking, ${ }^{*} \mathrm{PM}_{2} \rightarrow$ treatments after cooking (porridge).

$\mathrm{B}_{1} \mathrm{PM}_{1}=100 \%$ of Bulla flour, $\mathrm{OB}_{1} \mathrm{PM}_{1}=30 \%$ OFSP $+70 \%$ of Bulla, $\mathrm{OB}_{2} \mathrm{PM}_{1}=35 \%$ OFSP $+65 \%$ of Bulla, $\mathrm{OB}_{3} \mathrm{PM}_{1}=40 \%$ OFSP $+60 \%$ of Bulla and $\mathrm{OB}_{4} \mathrm{PM}_{1}=45 \%$ OFSP $+55 \%$ of Bulla composite flour; $\mathrm{B}_{1} \mathrm{PM}_{2}=100 \%$ Bulla porridge, $\mathrm{OB}_{1} \mathrm{PM}_{2}=30 \%$ OFSP $+70 \%$ Bulla, $\mathrm{OB}_{2} \mathrm{PM}_{2}=35 \%$ OFSP $+65 \%$ of Bulla, $\mathrm{OB}_{3} \mathrm{PM}_{2}=40 \%$ OFSP $+60 \%$ Bulla and $\mathrm{OB}_{4} \mathrm{PM}_{2}=45 \%$ OFSP $+55 \%$ Bulla composite flour porridge. Means $\pm \mathrm{SD}$, values within the same column with different superscript letters are significantly different from each other $(p<0.05)$.

As it is indicated in Table 4 the fat content of OFSP added Bulla composite flour and porridge were ranged from $0.26-0.70 \%$ and $0.22-0.82 \%$, respectively. The present studied samples were slightly different from Minaleshewa [2] fat content observed value ranged from 0.2 to $0.4 \mathrm{~g} / 100 \mathrm{~g}$. The fat content of the OFSP added Bulla composite flours and porridges were significantly different $(\mathrm{p}<0.05)$ to each other. The highest and lowest fat content values were observed for $\mathrm{OB}_{4} \mathrm{PM}_{2}(0.82 \%)$ and $\mathrm{B}_{1} \mathrm{PM}_{2}(0.22 \%)$, respectively. However, fat content of Bulla composites were not enough to satisfying the daily requirements of adult person. The results indicating that both Bulla and OFSP are poor sources of crude fat.

Table 4 show that the carbohydrate content of OFSP added Bulla composite flour ranged from 48.78 to $63.31 \%$, while that of porridge ranged from 35.00 to $48.63 \%$. The highest and lowest carbohydrate content values were observed for composite flour $\mathrm{OB}_{4} \mathrm{PM}_{1}(63.31 \%)$ and porridge $\mathrm{B}_{1} \mathrm{PM}_{2}(35 \%)$, respectively. According to Minaleshewa [2] the carbohydrate content of Bulla recorded to be 43.6 to $55.4 \mathrm{~g} / 100 \mathrm{~g}$, which was less than from the present study finding. There were significant difference $(p<0.05)$ observed between carbohydrate content of the composite flours and porridges. Due to the dilution of more water for porridge processing, the sample contained high amount of water. On the other hand as the percentage of OFSP is increased the carbohydrate content of both the composite flours and porridges were significantly increased. The carbohydrate content of the Bulla composite flour products were somehow enough for satisfying daily requirements of adult person. The findings indicating both Bulla and OFSP were good sources of carbohydrate. The RDA of carbohydrate for healthy person was found to be $130 \mathrm{~g} / \mathrm{day}$ [18].

The gross energy content of OFSP added Bulla composite flours and porridges were ranged from 201.07 268.11 and $149.58-211.11 \mathrm{Kcal} / 100 \mathrm{gm}$, respectively. The highest gross energy content was found for $\mathrm{OB}_{4} \mathrm{PM}_{1}$ $(268.11 \mathrm{Kcal} / 100 \mathrm{gm})$, while the least was for $\mathrm{B}_{1} \mathrm{PM}_{2}(149.58 \mathrm{Kcal} / 100 \mathrm{gm})$. The gross energy content were significantly different from each other $(\mathrm{p}<0.05)$.

According to the study of Almaz [19] and Minaleshewa [2] the energy content of Bulla was scored 1860 and $1410-1950 \mathrm{~kJ} / \mathrm{kg}$, respectively which were different from present study. The highest energy content of composite flour and porridge were scored for $\mathrm{OB}_{4} \mathrm{PM}_{1}(268.11 \mathrm{Kcal} / 100 \mathrm{~g})$ and $\mathrm{OB}_{4} \mathrm{PM}_{2}(211.11 \mathrm{Kcal} / 100 \mathrm{~g})$, respectively. There were significant difference $(\mathrm{p}<0.05)$ between the energy content of composite flour and porridge. When the percentage of OFSP increases in the composite flour, the energy content of composite flour and porridge were 
enhanced gradually. This might be due to the relatively higher energy content of OFSP compared to Bulla. The results indicate that the composites are good source of energy.

As mentioned on the previously reported literatures, Bulla was poor in $\beta$-carotene content. Therefore, it can be enhanced by the application of $\beta$-carotene rich food items to improve the $\beta$-carotene of the diet. The effect of addition of OFSP on $\beta$-carotene content of Enset (Bulla) based composite flour and porridge is shown in Table 4 . The $\beta$-carotene content of solar drayed OFSP powder was scored $1280 \mu \mathrm{g} / 100 \mathrm{~g}$, while the $\beta$-carotene content of OFSP added Bulla composite flour values were ranged from 386.68 to $558.05 \mu \mathrm{g} / 100 \mathrm{~g}$. Similarly, the $\beta$-carotene content of the OFSP added Bulla composite porridge values were ranged from 201.46 to $301.50 \mu \mathrm{g} / 100 \mathrm{~g}$. The highest $\beta$-carotene content observed for the composite flour $\mathrm{OB}_{4} \mathrm{PM}_{1}(558.05 \mu \mathrm{g} / 100 \mathrm{gm})$ followed by $\mathrm{OB}_{3} \mathrm{PM}_{1}$ $(515.58 \mu \mathrm{g} / 100 \mathrm{gm})$ and the least was observed for porridge $\mathrm{OB}_{1} \mathrm{PM}_{2}(201.46 \mu \mathrm{g} / 100 \mathrm{gm})$. The $\beta$-carotene content of composite flours and porridge were found to be significantly different $(\mathrm{p}<0.05)$ to each other. According to the study of Stella [6] and Aurélie [20] the $\beta$-carotene content of raw OFSP was observed in the ranged values from 1,255 to 2,400 and 1,596 to $2,382 \mu \mathrm{g} / 100 \mathrm{~g}$ of edible portion, respectively which is different from present study. The $\beta$ carotene content of raw OFSP flour comparing with the composite four was significantly different $(\mathrm{p}<0.05)$. This might be due to the degradation of $\beta$-carotene in the drying process and mixing with food having none $\beta$-carotene.

The $\beta$-carotene content of composite flour is significantly higher than bulla based porridge $(\mathrm{p}<0.05)$. This might be due to the effect of cooking temperature on $\beta$-carotene content in the preparation of the porridge. On the other hand when the percentage of OFSP increases, the $\beta$-carotene content of composite flour and porridge enhanced gradually. This is due to the higher $\beta$-carotene content of OFSP compared to Bulla. The results indicate that the composites were good source of $\beta$-carotene even though it is less than the one indicated by Stella [6] and Aurélie [20].

According to Kósambo [21] the average $\beta$-carotene loss on the finished products of porridge made from OFSP flour was $65 \%$. In the present study the loss of $\beta$-carotene content during cooking process of OFSP and Bulla composite flour porridge was $256.55 \mu \mathrm{g} / 100 \mathrm{~g}(45.97 \%)$. The finding show that the $\beta$-carotene degradation decreased. This might be due to short cooking time, temperature and genetic variation of the crop.

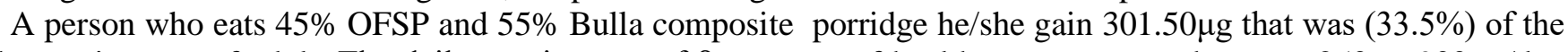
daily requirement of adult. The daily requirement of $\beta$-carotene of healthy person range between 250 to $900 \mu \mathrm{g} / \mathrm{day}$ $[17,18]$.

\subsection{Physical and Functional Properties Composite Flours or/and Porridge}

Table-5. Physical and functional properties, and $\mathrm{pH}$ of bulla based composite flours and porridge

\begin{tabular}{l|l|l|l|l}
\hline Treatment & $\mathbf{p H} / \mathbf{1 0 0 m g}$ & Bulk density, g/ml & $\mathbf{W A C}, \mathbf{g} / \mathbf{m l}^{\mathbf{3}}$ & Viscosity, cps \\
\hline Composite flours & & & & \\
\hline $\mathrm{B}_{1} \mathrm{PM}_{1}$ & $4.0 \pm 0.01 \mathrm{c}$ & $0.92 \pm 0.01 \mathrm{a}$ & $0.76 \pm 0.00 \mathrm{e}$ & \\
\hline $\mathrm{OB}_{1} \mathrm{PM}_{1}$ & $4.46 \pm 0.01 \mathrm{c}$ & $0.80 \pm 0.01 \mathrm{~b}$ & $1.70 \pm 0.10 \mathrm{~d}$ & - \\
\hline $\mathrm{OB}_{2} \mathrm{PM}_{1}$ & $5.27 \pm 0.01 \mathrm{~b}$ & $0.69 \pm 0.02 \mathrm{c}$ & $3.07 \pm 0.12 \mathrm{c}$ & - \\
\hline $\mathrm{OB}_{3} \mathrm{PM}_{1}$ & $5.64 \pm 1.15 \mathrm{~b}$ & $0.61 \pm 0.01 \mathrm{~d}$ & $4.00 \pm 0.00 \mathrm{~b}$ & - \\
\hline $\mathrm{OB}_{4} \mathrm{PM}_{1}$ & $5.71 \pm 0.03 \mathrm{a}$ & $0.58 \pm 0.01 \mathrm{e}$ & $4.87 \pm 0.15 \mathrm{a}$ & - \\
\hline Porridge $_{\mathrm{B}} \mathrm{PM}_{2}$ & & & & \\
\hline $\mathrm{OB}_{1} \mathrm{PM}_{2}$ & $5.13 \pm 0.01 \mathrm{c}$ & & & $515 \pm 1.00 \mathrm{e}$ \\
\hline $\mathrm{OB}_{2} \mathrm{PM}_{2}$ & $5.71 \pm 0.00 \mathrm{a}$ & - & - & $525.67 \pm 0.58 \mathrm{~d}$ \\
\hline $\mathrm{OB}_{3} \mathrm{PM}_{2}$ & $5.73 \pm 0.01 \mathrm{a}$ & - & - & $553.00 \pm 1.00 \mathrm{c}$ \\
\hline $\mathrm{OB}_{4} \mathrm{PM}_{2}$ & $5.77 \pm 0.01 \mathrm{a}$ & - & - & $624.67 \pm 0.58 \mathrm{~b}$ \\
\hline
\end{tabular}

Note: ${ }^{*} \mathrm{PM}_{1} \rightarrow$ treatments before cooking, ${ }^{*} \mathrm{PM}_{2} \rightarrow$ treatments after cooking.

$\mathrm{B}_{1} \mathrm{PM}_{1}=100 \%$ of Bulla flour, $\mathrm{OB}_{1} \mathrm{PM}_{1}=30 \%$ OFSP $+70 \%$ of Bulla, $\mathrm{OB}_{2} \mathrm{PM}_{1}=35 \%$ OFSP $+65 \%$ of Bulla, $\mathrm{OB}_{3} \mathrm{PM}_{1}=40 \%$ OFSP $+60 \%$ of Bulla and $\mathrm{OB}_{4} \mathrm{PM}_{1}=45 \%$ OFSP $+55 \%$ of Bulla composite flour; $\mathrm{B}_{1} \mathrm{PM}_{2}=100 \%$ Bulla porridge, $\mathrm{OB}_{1} \mathrm{PM}_{2}=30 \%$ OFSP $+70 \%$ Bulla, $\mathrm{OB}_{2} \mathrm{PM}_{2}=35 \%$ OFSP $+65 \%$ of Bulla, $\mathrm{OB}_{3} \mathrm{PM}_{2}=40 \%$ OFSP $+60 \%$ Bulla and $\mathrm{OB}_{4} \mathrm{PM}_{2}=45 \%$ OFSP $+55 \%$ Bulla composite flour porridge. Means $\pm \mathrm{SD}$, values within the same column with different superscript letters are significantly different from each other $(p<0.05)$. WAC-water absorption capacity, cps-centi pose second.

The $\mathrm{pH}$ value of Bulla was 4.00/100mg; OFSP added Bulla composite flour and porridge were found in the range from 4.46-5.82/100mg as presented in Table 5. The highest $\mathrm{pH}$ value observed for bulla based porridge $\mathrm{OB}_{4} \mathrm{PM}_{2}$ $(5.82 / 100 \mathrm{mg})$, while the least value was seen for composite flour $\mathrm{B}_{1} \mathrm{PM}_{1}(4.00 / 100 \mathrm{mg})$. This might be due to cooking temperature increases the $\mathrm{pH}$ value of the samples by denaturing the amino acids in the food. As the percentage of OFSP increases, the $\mathrm{pH}$ value of composite flour and porridge were enhanced.

The composite flour $\mathrm{pH}$ values were significantly different $(\mathrm{p}<0.05)$ to each other. While the $\mathrm{pH}$ values for porridges were not significantly different $(p>0.05)$ to each other. According to the study of Kalekristos [3] Bulla bought from Addis Ababa supper market $\mathrm{pH}$ value was 4.9/100mg which was less acidic compared to present study.

As mentioned in previous sections, the bulk density of a powder depends on how closely individual particles packed together and it play important roles during mixing in dough formation [14]. The bulk densities for Bulla was $0.92 \mathrm{~g} / \mathrm{ml}$, OFSP added Bulla composite flour were ranged from $0.58-0.91 \mathrm{~g} / \mathrm{ml}$. The highest bulk densities was observed for $\mathrm{B}_{1} \mathrm{PM}_{1}(0.92 \mathrm{~g} / \mathrm{ml})$ while the least was for $\mathrm{OB}_{4} \mathrm{PM}_{1}(0.58 \mathrm{~g} / \mathrm{ml})$. The bulk densities of OFSP added Bulla composite flours were significantly different from each other $(\mathrm{p}<0.05)$. As the amount of OFSP powder increases in the composite, the bulk density decreased gradually. This is due to particle size of OFSP is less than Bulla.

The water absorption capacity of flour indicates how much water to add during food preparation and interrelated to gelatin properties. Hence, the low water absorption capacity recorded by the flours could explain the less gel formation capacity [16]. The finding of the water absorption capacity of Bulla in this study was $0.76 \mathrm{ml} / \mathrm{g}$, while the 
water absorption capacity of OFSP added Bulla composite flours were ranged from 1.70 to $4.87 \mathrm{ml} / \mathrm{g}$ as shown in Table 5. As the amount of OFSP flour increases in the composite, the water absorption capacity increased gradually. This might be due to the water absorption capacity of OFSP powder was higher compared to Bulla flour. The highest water absorption capacity of OFSP added Bulla composite was for $\mathrm{OB}_{4} \mathrm{PM}_{1}\left(4.87 \mathrm{~g} / \mathrm{ml}^{3}\right)$ and the least was for $\mathrm{B}_{1} \mathrm{PM}_{1}$ $\left(0.76 \mathrm{~g} / \mathrm{ml}^{3}\right)$. There were significantly different from each other $(\mathrm{p}<0.05)$.

The value of viscosity of Bulla porridge was 515.00 c.p.s, OFSP added Bulla composite flours porridge were ranged from 525.67-728.00 c.p.s. (see above Table 5). The highest viscosity value was observed for $\mathrm{OB}_{4} \mathrm{PM}_{2}(728.00$ c.p.s) followed by $\mathrm{OB}_{3} \mathrm{PM}_{2}$ (624.67) and the least for $\mathrm{B}_{1} \mathrm{PM}_{2}$ (515.67 c.p.s.). There were significantly difference $(\mathrm{p}<0.05)$ between each treatment. As the amount of OFSP flour increases in the composite flours, the viscosity of the porridge was also increased. This might be due to the water absorption capacity of the OFSP flour. The higher the viscosity is a desirable quality attribute of flour for cooking purpose. Liquids make up of small molecules have a low viscosity and liquids with long chain molecules have a much higher viscosity [22].

\subsection{Sensory Evaluation of Bulla Based Composite Flours Porridge}

Table-5. Organoleptic evaluation score of OFSP added Bulla composite flours porridge

\begin{tabular}{l|l|l|l|l}
\hline \multicolumn{4}{l|}{ Parameters } & \multicolumn{4}{l}{ Odor } & Flavor & Overall acceptability \\
\hline Porridge & Color & $1.00 \pm 00 \mathrm{e}$ & $1.30 \pm 1.00 \mathrm{e}$ & $1.25 \pm 0.30 \mathrm{e}$ \\
\hline $\mathrm{B}_{1} \mathrm{PM}_{2}$ & $1.05 \pm 0.12 \mathrm{e}$ & $2.62 \pm 1.09 \mathrm{~d}$ & $2.60 \pm 1.06 \mathrm{~d}$ & $2.58 \pm 0.99 \mathrm{~d}$ \\
\hline $\mathrm{OB}_{1} \mathrm{PM}_{2}$ & $2.63 \pm 1.08 \mathrm{~d}$ & $2.84 \pm 0.85 \mathrm{c}$ & $2.83 \pm 0.80 \mathrm{c}$ & $2.89 \pm 0.77 \mathrm{c}$ \\
\hline $\mathrm{OB}_{2} \mathrm{PM}_{2}$ & $2.80 \pm 0.78 \mathrm{c}$ & $3.36 \pm 0.95 \mathrm{~b}$ & $3.37 \pm 1.05 \mathrm{~b}$ & $3.53 \pm 0.94 \mathrm{~b}$ \\
\hline $\mathrm{OB}_{3} \mathrm{PM}_{2}$ & $3.36 \pm 0.92 \mathrm{~b}$ & $4.33 \pm 0.82 \mathrm{a}$ & $4.39 \pm 0.83 \mathrm{a}$ & $4.45 \pm 0.76 \mathrm{a}$ \\
\hline $\mathrm{OB}_{4} \mathrm{PM}_{2}$ & $4.28 \pm 0.87 \mathrm{a}$ & &
\end{tabular}

Note: $* \mathrm{PM}_{1} \rightarrow$ treatments before cooking, ${ }^{*} \mathrm{PM}_{2} \rightarrow$ treatments after cooking.

$\mathrm{B}_{1} \mathrm{PM}_{1}=100 \%$ of Bulla flour, $\mathrm{OB}_{1} \mathrm{PM}_{1}=30 \%$ OFSP $+70 \%$ of Bulla, $\mathrm{OB}_{2} \mathrm{PM}_{1}=35 \%$ OFSP $+65 \%$ of Bulla, $\mathrm{OB}_{3} \mathrm{PM}_{1}=40 \%$ OFSP $+60 \%$ of Bulla and $\mathrm{OB}_{4} \mathrm{PM}_{1}=45 \%$ OFSP $+55 \%$ of Bulla composite flour; $\mathrm{B}_{1} \mathrm{PM}_{2}=100 \%$ Bulla porridge, $\mathrm{OB}_{1} \mathrm{PM}_{2}=30 \%$ OFSP $+70 \%$ Bulla, $\mathrm{OB}_{2} \mathrm{PM}_{2}=35 \%$ OFSP $+65 \%$ of Bulla, $\mathrm{OB}_{3} \mathrm{PM}_{2}=40 \%$ OFSP $+60 \%$ Bulla and $\mathrm{OB}_{4} \mathrm{PM}_{2}=45 \%$ OFSP $+55 \%$ Bulla composite flour porridge. Means $\pm \mathrm{SD}$, values within the same column with different superscript letters are significantly different from each other $(\mathrm{p}<0.05)$.

The porridges were prepared by blending of OFSP and Bulla in different combination were analyzed for various sensorial attributes for their acceptance by using 5 point hedonic scale. When you are offering a new product or changing ingredients of food items, it is important to know what likely the consumer reaction is to be to the characteristics of your product. At the present study all panelists were instructed to make their own individual assessments, according to the evaluation criteria provided for each samples on the basis of, color, odor, flavor and overall acceptability. The organoleptic evaluation of OFSP and Bulla composite flours porridge score values ranged from 1.05-4.28, 1.00-4.33, 1.3-4.39 and 1.25-4.45 for attributes of color, odor, flavor and overall acceptability, respectively as indicated in above Table 6 . There were Significant difference $(p<0.05)$ was observed among the treatments. The highest preferences of Bulla composite porridge by color, odor, flavor and overall acceptability were scored 4.28, 4.33, 4.39 and 4.45, respectively. It was observed that the Bulla based porridge sample $\mathrm{OB}_{4} \mathrm{PM}_{2}$, prepared by addition of $45 \%$ OFSP flour was liked most by sensory panelist as compared to the other combinations. The least preferred Bulla composite porridge $\mathrm{OB}_{1} \mathrm{PM}_{2}$ was scored 1.05, 1.00, 1.30 and 1.25 for color, odor, flavor and overall acceptability, respectively. The evaluation results of the panelist's preferences were increases as the ratio of OFSP increases in the composite flours.

\section{Conclusion}

As Orange-fleshed Sweet Potato (OFSP) percentage increased in the composite flours and porridge; gross energy, $\beta$-carotene content, $\mathrm{pH}$, water absorption capacity and viscosity were enhanced. However, an increased amount of OFSP in Bulla flour and its corresponding products do not made them to be good source of crude fiber, protein and fat. The composite flours porridge $\mathrm{OB}_{4} \mathrm{PM}_{2}$ was preferred by panelists in terms of the sensory attributes of color, odor, flavor and overall acceptability.

\section{References}

[1] N. Almaz and N. Anke, "The significance of enset culture and biodiversity for rural household food and livelihood security in South Western Ethiopia. Wageningen university and research center," Agriculture and Human Values, pp. 62-65, 2004.

[2] A. Minaleshewa, "Studies on commercially available enset (Enseteventricosum Welw.Cheesman) food products (Kocho and Bulla) for major, minor and trace elements," Thesis of in Partial Fulfillment of Requirements for the M.Sc. Graduate Project (Chemistry.774) Addis Ababa University, 2007.

[3] Y. Kalekristos, "Studies on of influence of baking time and temperature on the quality of kocho biscuit enriched with faba bean and wheat," In Partial Fulfillment of the Requirements for the M.Sc. Thesis of Institute of Technology Department of Chemical Engineering Addis Ababa University, Ethiopia, 2010

[4] A. Tilahun, S. Ann, and A. Jens, "Advancing human nutrition without degrading land resources through modeling cropping systems in the Ethiopian High Lands. The United Nations university," Food and Nutrition Bulletin, vol. 25, pp. 344-351, 2004.

[5] T. Assefa, T. Engida, A. Teshome, and T. Tesfaye, "Summary of progress on orange-fleshed sweet potato research and development in Ethiopia," in Proceedings of the 13th ISTRC Symposium, Arushac 2007 Tanzania, 2007, pp. 728 - 730.

[6] O. Stella, Promotion of high quality sweet potato flour in the food industry, evidence from rural women in Nigeria university. Ibadan, Nigeria, 2004

[7] L. Jan, U. Rafael, A. MariaIsabel, and H. Julie, "Orange-flesh sweet potato promising partnerships for assuring the integration of nutritional concerns into agricultural research and extension," pp. 1-4, 2000.

[8] Ethiopian National Guidelines for Control and Prevention of Micronutrient Deficiencies, Federal ministry of health family health department. Ethiopia, 2004. 
C. Owori, B. Lemaga, R. O. M. Mwanga, A. Namutebi, and R. Kapinga, "Sweet potato recipe book, sweet potato processed product from Eastern and central Africa Kampala Uganda. [Accessed January, 2014]," 2007.

[10] A. Yewelsew, B. J. Stoecker, M. J. Hinds, and G. E. Gates, "Nutritive value and sensory acceptability of corn and Kocho based foods supplemented with legumes for infant feeding in Southern Ethiopia," African Journal of Food Agriculture Nutrition and Development, vol. 6, pp. 3-13, 2006.

[11] A. Rodriguez, A. Rodriguez, and K. Mieko, "Assessment of provitamin A determination by Open Column Chromatography/visible absorption Spectrophotometery," Journal of Chromatographic Science, vol. 26, pp. 624-629, 1988.

[12] Association of Official Analytical Chemists (AOAC), Standard official methods of analysis of the association of analytical chemists, S.W. Williams (Ed), 14th ed. Washington, D C.: AOAC, 1984.

[13] M. Yirmaga, "Improving the indigenous processing of Kocho, an Ethiopian traditional fermented food. Nutrition \& food department of food science and post harvest technology. Institute of technology, Haramaya University, Ethiopia," Journal of Nutrition and Food Science, vol. 3, p. $1000182,2013$.

[14] A. K. Oladele and J. O. Aina, "Chemical composition and functional properties of flour produced from two varieties of tigernut (Cyperuse Sculentus). Department of food technology, University of Ibadan, Ibadan, Nigeria," African Journal of Biotechnology, vol. 6, pp. 2473-2476, 2007.

[15] S. K. Sathe and D. K. Salunkhe, "Functional properties of great northern bean (Phaseolus Vulgaris) proteins. Emulsion, foaming, viscosity and gelatin properties," Journal of Food Science, vol. 4, pp. 71-75, 1981.

[16] A. V. Ikujenlola, "Chemical and functional property of complementary food prepared from malted and un melted Achaea soybean and defatted sesame seed," Journal of Food Engineering and Applied Science, vol. 3, pp. 471-473, 2008.

[17] FAO Food Standards Program, "Codex alimentarius commission. Codex committee on vegetable proteins draft codex standard for wheat protein products including wheat gluten (Advanced to Step 8 of the Procedure) 24th Session Geneva, Switzerland," 2001.

[18] Food and Nutrition Board, "Dietary references of energy, carbohydrate, fiber, fat, fatty acid, protein and amino acid (Macronutrient). US department of agriculture, national agricultural library and national academy of sciences," Institute of Medicine, pp. 48, 107, 265, $339,422 \& 589,2005$

[19] N. Almaz, Diversity and conservation of enset (Enset Ventricosum Welw. Cheesman) and its relation to household food and livelihood security in South Western Ethiopia: Wageningen University, 2001.

[20] B. Aurélie, "Investigating of carotenoid loss after drying and storage of orange-fleshed sweet potato," A Thesis Submitted in Partial Fulfillment of the Requirements of the University of Greenwich PhD Thesis, 2010.

[21] L. Kósambo, "Effect of storage and processing on all trans $\beta$-carotene content in fresh sweet potato (Ipomoea BatatasL) roots and its products," Kenya Industrial Research and Development Institute Conference, Annual Report (July 2003 - June 2004) Kenya Industrial Research Project, Nairobi2004.

[22] P. A. Okorie, Functional and pasting properties of lesser known Nigerian yams as a function of blanching time and particle size. Department of food science and technology. Abakaliki: Ebonyi State University, 2011. 